Journal of Contemporary Research in Social Sciences

ISSN : 2641-0249

Vol. 2, No. 1, pp. 1-7

2020

Publisher: Learning Gate

DOI: 10.33094/26410249.2020.21.1.7

(C) 2020 by the authors; licensee Learning Gate

\title{
Determinants of Savings Behavior in Pakistan: An Empirical Evaluation Employing the ARDL Approach
}

\author{
Masood Mashkoor Siddiqi \\ Dean, Federal Urdu University Arts Science and Technology, Pakistan. \\ Email: drmasoodmashkoor@yahoo.com
}

Received: 2 January 2020; Revised: 23 January 2020; Accepted: 10 February 2020; Published: 20 February 2020

\begin{abstract}
This article purposes to define the long and short run associations among savings rate, growth rate of per capita GNP, real rate of interest, deficits of current account (DCAs) and the rate of inflation in Pakistan employing ARDL cointegration (approach) and ECM for the span of 1973 to 2014. The recently formulated ARDL cointegration (approach) is employed, that is relevant if the variables are stationary at level or first order. The Sign of variables are according to the theory, while apart from growth rate of per capita GNP; all variables are statistically significant in the long and short run. The results of the study help to recommend some policy options for economic managers.
\end{abstract}

Keywords: ARDL to cointegration, Saving growth, GDP, Pakistan, DCAs, Inflation.

JEL Classification: D14; D91; E21.

\section{Introduction}

Economist explain saving, as the gap between household's income and expenditure. This savings play essential part in the economic growth and development of various nations. These nations, described through feeble financial market, are enforced to depend over savings of household this investment plans. It is the national savings shortfall which is a standout amongst the crucial restraints over economic development and growth in the majority developing nations. Savings at countrywide level are expected to encourage investments at nationwide level that thusly will give the premise to more quick economic development and growth (Nurkse, 1953).

Pakistan is a developing nation along with a feeble financial market and is rely primarily over savings for funding investment within Pakistan. Pakistan's rate of saving, on the other hand, has been shown mix trend throughout the period. However, there is sharp increase in saving rates from 1999 to 2008, trend line shows upward trend in overall period. The average saving of this period is $14.62 \%$ of GDP. Taking into account of the significance of savings and the slightly upward direction during the last 34 years, this study undertakes to analyze the components and elements that have influenced savings in Pakistan Figure 1. 


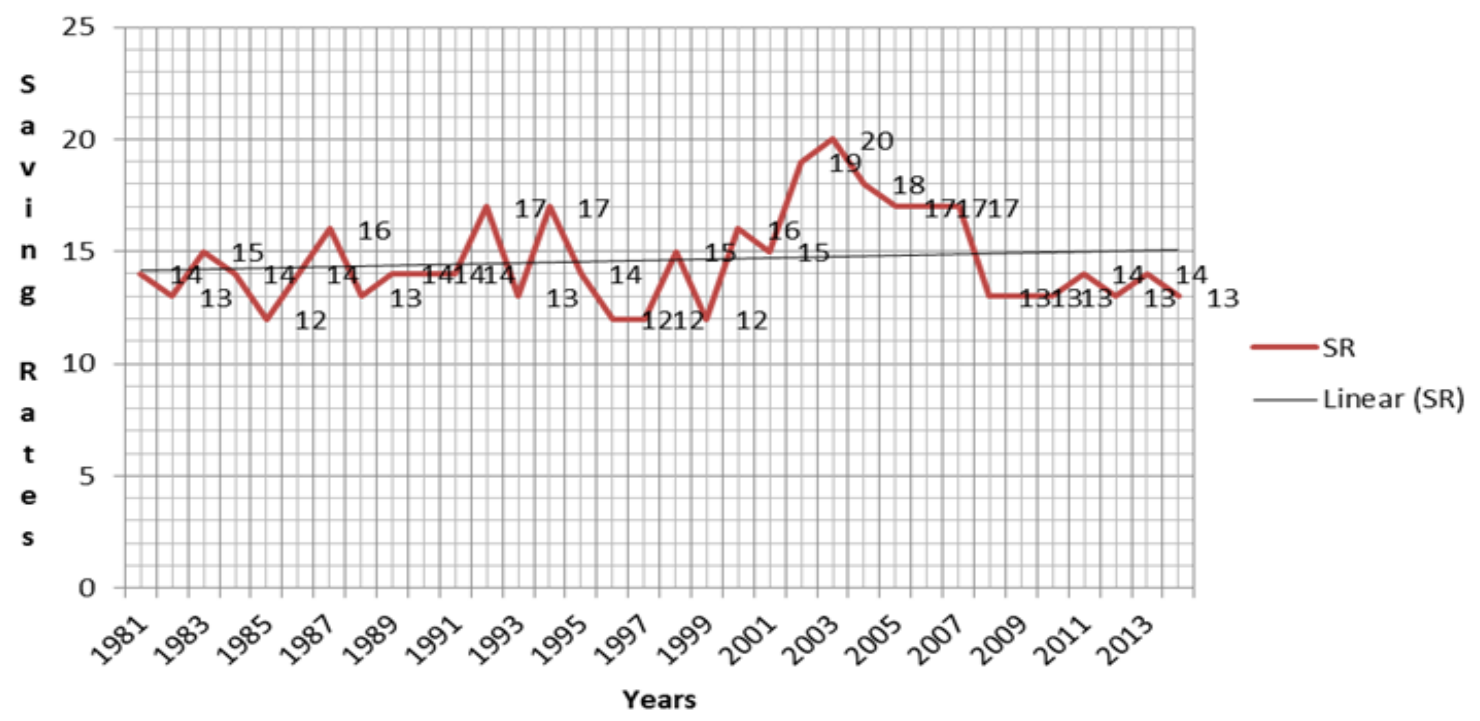

Figure-1. Saving rates.

There are different purposes behind attempting the current study. In the first place, except for a couple of recent research works Agrawal (2001); Sarantis and Stewart (2001); Narayan and Saud (2005); and Narayan and Saud (2005) over savings within developing nations, numerous research articles (Cardenas \& Escobar, 1998; Cook, 1995; Khan, Hasan, \& Malik, 1994) along with others are assailable to critique over econometric bases, for they overlook the way that variables utilized in modeling rates of saving are expected to have a unit root and non-stationary. Yule (1926) as well as Granger and Paul (1974) mentioned that derivation formed regarding long-term elasticities are possibly unsatisfactory as well as deceiving. Taking into account this restriction in the previous literature on the rate of savings determinants, this article endeavors to improve for specious regression through employing ARDL approach to cointegration examination within the newly formulated "autoregressive distributed lag (ARDL) framework" (Pesaran \& Shin, 1999) permitting estimations to be made of both long-run as well as short-run associations.

Second, in spite of the fact that studies about savings rate as long as set of nations and areas have multiplied inter alia (Callen, 1997; Dayal-Ghulati, 1997; Giovannini, 1983) the focal point has rarely been on a particular nation. Whereas this gap in theory may be because of the absence of correct time series data on developing nations, no such dilemma exists for Pakistan. The additional problem is that given the utilization of cross-sectional data examination in numerous studies, one can't legitimately gather from perceptions crosswise over nations at a point in time what may happen in a nation over the long run. A period arrangement study beats this issue, giving a stronger premise for educated strategy making.

The focal point of this study is to outline the short-run and long-run associations among saving rate, real rate of interest, growth of per capita income, deficits of current account (DCA) and ratio of dependency in Pakistan utilizing ARDL to cointegration and ECM over the period 1973-2014.

The remaining parts of this study are composed in the following manner. In segment 2 , previous literature as well as theoretical framework is examined. In segment 3, the model will be delineated. In segment 4, the econometric technique will be examined, and in Section 5, the empirical and observational results will be analyzed. The last segment closes with some policy and strategy ramifications. 


\subsection{Objectives of the Study}

The primary objectives of the study considered are to empirically examine the important determinants of savings and its impact on real rate of growth in case of Pakistan including specific objectives as under:

i. Review saving trends in Pakistan.

ii. To empirically found the factors that affects the savings regarding Pakistan's economy.

iii. Recommendations for economic managers for increasing savings to favorable level.

iv. To ascertain the impact of savings on overall level of economic growth.

\subsection{Contribution of the study}

The said study is contributed in existing literature with more efficient techniques and reliable outcomes that will be helpful to understand the effects of savings on economic growth and its determinants. Pakistan's economy is continuously affected by negative shocks; there is a need to focus on literature related to productivity improvement through more savings. More of the literature focused on static aspects of macroeconomic models whereas, this study focus on dynamic aspects of macroeconomic modeling in order to achieve more reliable findings.

\section{Review of Previous Literature}

Following on from different research work over the factors that determine savings rate such as Giovannini (1983); Doshi (1994); Agrawal (2001) The "life cycle" theory competes that current decisions about savings of households are a result of a demonstration to allocate their life span expenditure consistently over their lives in order to keep up the same way of life throughout retirement (Modigliani, 1970). In short, according to Modigliani (1970) savings rate, age structure and/or growth of income of the population are associated.

Concerning the income growth rate, the life cycle hypothesis hypothesizes a direct association between rate of savings and growth rate of income, while higher growth rate of income makes the youth wealthier than the elders; subsequently the portion of population who are young will be sparing more income than the older portion of population will be sparing less income. Some current research studies demonstrate this association to be valid for some developing nations (Agrawal, 2001). In any case, it is likewise conceivable that the impact of the economic growth will be favorable just to the extent that households, generally, hoard wealth while people are working so as to spend this wealth at the time they are retired. If households dispose earlier than they earn their income by borrowing than growth rates might unfavorably influence savings rate. Besides, the growth rate will have practically no impact on national savings if the dependency ratio is high. Different research studies conclude that an inverse association between the two variables is likewise conceivable such as Carroll (1991). Their contention is focused around the thought that, different things being equivalent, an independent increment in level of growth, increase the income of consumers and therefore enhance their expenditure levels, prompting a lesser savings rate. Against this foundation, the expected sign of the rate of savings and growth is uncertain.

The population age structure is as well observed like a critical savings determinant in the life cycle hypothesis given that a decreasing portion of the population who is not working to working population is supposed to associate along higher rates of savings. Be that as it may, the presented empirical confirmation over this association is diverse. Such as, Leff (1969) demonstrated that this is valid for the developing as well as the developed nations, whereas Kelley (1988) and Doshi (1994) discovered no or exceptionally weak support of this association between dependency ratio and rate of savings the in developing nations. Agrawal (2001) discovered a critical inverse association between dependency ratio and rate of savings for three of the seven Asian nations.

With the exception of the life cycle hypothesis, we employ and real rate of interest as extra independent variables, Agrawal (2001). The association between DCA and national savings like a part of 
GNP is straightforward: large international savings directs to a drop in domestic savings, because both of them are alternates.

The rate of interest in real terms, characterized like the distinction in the middle of the nominal rate of interest and the estimated inflation, is the benefit as long as putting off current consumption for the sake of future consumption. The association between rate of savings and real rate of interest is vague as long as empirical and theoretical literature is concerned; however the typical assumption is so as to the aggregate impact is positive. The primary purposes behind vagueness follows from the difference between the resultant substitution and income effects from a rate of interest change (Agrawal, 2001; Giovannini, 1983). The general effect of rate of interest over savings could be direct or inverse relying upon which impact is bigger. Subsequently, the direction of relationship is different issue relying on the comparative power of substitution and income effects. If the income impact is offset by the substitution impact then the savings possibly increase because of enhance in real rate of interest. Fry (1995) and Fry (1995) discovered so as to the savings and rate of interest contain a direct although little association whereas (Giovannini, 1983) described no significant association between interest rates and savings. Agrawal (2001) establish diverse outcomes on this association as long as four different Asian nations are concerned.

\section{Empirical Model Description}

Derived from review of literature within preceding segment, the following empirical model is hypothesizing to find out rate of national savings for Pakistan.

$$
\mathrm{SR}_{\mathrm{t}}=\beta_{0}+\beta_{1} \mathrm{GR}_{\mathrm{t}}+\beta_{2} \mathrm{IR}_{\mathrm{t}}+\beta 3 \mathrm{DCAt}+\beta_{4} \mathrm{IFR}_{\mathrm{t}}+\mu_{\mathrm{t}}(1)
$$

where $\mathrm{SR}_{\mathrm{t}}$ is the rate of savings which is computed as a proportion of GNSs to GNP; $\mathrm{GR}_{\mathrm{t}}$ is the rate of growth of income each person; $\mathrm{IR}_{\mathrm{t}}$ is the real rate of interest; DCAt is the deficit of current account as a ratio of GNP; and IFR $\mathrm{t}_{\mathrm{t}}$ is the inflation rate. $\beta 3$ and $\beta_{4}$ are expected to be negative, whereas $\beta_{1}$ and $\beta_{2}$ are expected to be positive.

\section{Methodology}

The Empirical techniques in this study describe below:

i) Unit Root Test:

The critical position for the long-term association between these variables is their stationary ranks in the ARDL to Cointegration approach. In (1979) Dickey-Fuller established ADF test to test stationary ranks of each variable individually.

ii) ARDL to Cointegration Approach:

In Pesaran and Shin (1999) establish the ARDL to Cointegration approach to assessing the cointegration. The ARDL to Cointegration approach is different from other methods that seek long-term association among variables; the ARDL to Cointegration approach does not compel a restrictive supposition that all variables must be stationary at the same rank. Pesaran and Shin (1999) ARDL to Cointegration approach is employed without taking care of whether the entire variables are stationary at zero or at first level. This method is apposite even with the small sample size. Furthermore, it takes include $\operatorname{lag}(\mathrm{s})$ to detain the data creating procedure in a deductive modeling structure.

iii) Error Correction Model:

The ECM was employed by Sargan and afterward implemented by Granger (1969) accurate for disequilibrium. A vital theorem, known as "the Granger representation theorem", depicts that if variables have a long-term association, then the short-term association among them can be articulated as ECM.

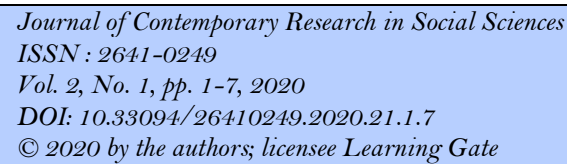




\section{Empirical Analysis and Outcomes}

Table-1. Unit root test (ADF).

\begin{tabular}{c|c|c|c|c}
\hline Variables & Calculated value & $\mathbf{1 \%}$ Critical value & $\mathbf{5 \%}$ Critical value & Probability * \\
\hline $\mathrm{SR}(6)$ & -2.853951 & -4.243644 & -3.544284 & 0.1890 \\
\hline $\mathrm{D}(\mathrm{SR})(\mathrm{O})$ & -9.456444 & -4.205004 & -3.526609 & 0.0000 \\
\hline $\mathrm{DCA}(\mathrm{O})$ & -4.172078 & -4.198503 & -3.523623 & 0.0107 \\
\hline $\mathrm{D}(\mathrm{DCA})(9)$ & -4.298020 & -4.284580 & -3.562882 & 0.0097 \\
\hline $\mathrm{IFR}(\mathrm{O})$ & -1.256638 & -4.111503 & -3.783623 & 0.8297 \\
\hline $\mathrm{D}(\mathrm{IFR})(\mathrm{O})$ & -5.620461 & -4.675074 & -3.666609 & 0.0000 \\
\hline $\mathrm{GR}(\mathrm{O})$ & -5.124184 & -4.198503 & -3.523623 & 0.0008 \\
\hline $\mathrm{D}(\mathrm{GR})(1)$ & -6.939380 & -4.211868 & -3.529758 & 0.0000 \\
\hline $\mathrm{IR}(\mathrm{O})$ & -3.730956 & -4.198503 & -3.523623 & 0.0313 \\
\hline $\mathrm{D}(\mathrm{IR})(1)$ & -6.996921 & -4.211868 & -3.529758 & 0.0000 \\
\hline
\end{tabular}

Notes: Y: The Level form of the variable $\mathrm{Y}, \Delta(\mathrm{Y})$ : The first difference of the variable $\mathrm{Y} . \Delta(\mathrm{Y}, 2)$ : The second difference of the variable Y. *MacKinnon (1996) one-sided p-values.

Table 1 exemplifies the final results of ADF test and apart from SR and DEPR the entire preferred variables are non-stationary at level and remaining at first difference.

Table-2. Autoregressive distributed lag estimates.

\begin{tabular}{c|c|c|c}
\hline Regressors & Coefficient & Standard Error & T-Ratio[Prob] \\
\hline SR(Lag1) & 0.43209 & 0.12815 & $3.3719[0.002]$ \\
\hline DCA & -0.00656 & 0.00157 & $-4.1668[0.000]$ \\
\hline DCA(Lag1) & 0.00468 & 0.00174 & $2.6904[0.012]$ \\
\hline DCA(Lag2) & -0.00469 & 0.00161 & $-2.9116[0.007]$ \\
\hline IFR & -0.00245 & 0.01014 & $-.32799[0.791]$ \\
\hline IFR(Lag1) & -0.00372 & 0.01594 & $-.13402[0.885]$ \\
\hline IFR(Lag2) & 0.01790 & 0.01058 & $1.6917[0.101]$ \\
\hline GR & $0.359 \mathrm{E}-3$ & $0.4231 \mathrm{E}-3$ & $0.8485[0.403]$ \\
\hline IR & 0.00123 & $0.7079 \mathrm{E}-3$ & $1.7402[0.092]$ \\
\hline CONSTANT & 0.06843 & 0.02024 & $3.3806[0.002]$ \\
\hline TREND & $0.1067 \mathrm{E}-3$ & 0.3013E-3 & $.35394[0.726]$ \\
\hline R $^{2}$ & 0.75247 & Heteroscedasticity & $1.2092[0.278]$ \\
\hline Adjusted R ${ }^{2}$ & 0.66712 & F-stat. F( 10, 29) & $8.8158[0.000]$ \\
\hline DW-statistic & 2.1982 & Serial Correlation & $1.3646[0.253]$
\end{tabular}

ARDL Approach to Cointegration Analysis: Table 2 ARDL approach to Cointegration technique demonstrates that the entire chosen variables have a long-term association with F-stat. 8.81 and p-value 0.000 .

Table-3. Diagnostic tests.

\begin{tabular}{c|c}
\hline Diagnostic Tests & Statistics \\
\hline Serial Correlation & $\mathrm{F}(1,28)=1.3646[0.253]$ \\
\hline Functional Form & $\mathrm{F}(1,28)=2.4733[0.127]$ \\
\hline Normality & $\mathrm{CHSQ}(2)=0.21805[0.897]$ \\
\hline Durbin's h-statistic & $\mathrm{F}(1,28)=-1.0701[0.285]$ \\
\hline
\end{tabular}


Diagnostic Tests: Table 3 shows all diagnostic tests are statistically significant and indicate that there are no problems found in model.

Table-4. Estimated long run coefficients using the ARDL approach.

\begin{tabular}{c|c|c|c}
\hline Regressors & Coefficient & Standard Error & T-Ratio [Prob] \\
\hline DCA & -0.011582 & 0.0042570 & $-2.7206[0.011]$ \\
\hline IFR & -0.023340 & 0.0087533 & $-2.6129[0.014]$ \\
\hline GR & $0.6321 \mathrm{E}-3$ & $0.7532 \mathrm{E}-3$ & $0.8392[0.408]$ \\
\hline IR & 0.0021691 & 0.0012522 & $1.7323[0.094]$ \\
\hline CONSTANT & 0.12051 & 0.033682 & $3.5779[0.001]$ \\
\hline TREND & $0.1878 \mathrm{E}-3$ & $0.5074 \mathrm{E}-3$ & $0.37011[0.714]$ \\
\hline
\end{tabular}

The Table 4 presents the calculated long-term coefficients using an ARDL approach to Cointegration, which illustrates that SR is very much influenced with DCA, IFR, and IR in the long run. The given table identified that DCA and IFR are statistically significant and have expected signs (a prior expectation). Similarly, GR and IR also exhibit a prior expectations justification but GR is not statistically significant. However, the regression result indicated that all selected variables except GR have played a significant role in the long run on saving rate.

Table-5. Error correction representation for the selected ARDL model.

\begin{tabular}{c|c|c|c}
\hline Regressors & Coefficient & Standard Error & T-Ratio[Prob] \\
\hline D(DCA) & -0.0065645 & 0.0015754 & $-4.1668[0.000]$ \\
\hline $\mathrm{D}(\mathrm{DCA})(\operatorname{lag} 1)$ & 0.0046970 & 0.0016132 & $2.9116[0.007]$ \\
\hline $\mathrm{D}(\mathrm{IFR})$ & -0.0023037 & 0.010104 & $-0.2280[0.821]$ \\
\hline $\mathrm{D}(\mathrm{IFR})(\mathrm{lag} 1)$ & -0.017904 & 0.010584 & $-1.6917[0.101]$ \\
\hline $\mathrm{D}(\mathrm{GR})$ & $0.3590 \mathrm{E}-3$ & $0.4231 \mathrm{E}-3$ & $0.8485[0.403]$ \\
\hline $\mathrm{D}(\mathrm{IR})$ & 0.0012319 & $0.7079 \mathrm{E}-3$ & $1.7402[0.092]$ \\
\hline $\mathrm{D}(\mathrm{CONSTANT})$ & 0.068439 & 0.020245 & $3.3806[0.002]$ \\
\hline $\mathrm{D}(\mathrm{TREND})$ & $0.1067 \mathrm{E}-3$ & $0.3013 \mathrm{E}-3$ & $0.35394[0.726]$ \\
\hline ECT $($ lag 1$)$ & -0.56791 & 0.12815 & $-4.4317[0.000]$ \\
\hline $\mathrm{R}^{2}$ & 0.70311 & F-stat. F $(8,31)$ & $8.5850[0.000]$ \\
\hline Adjusted $^{2}$ & 0.60074 & DW-statistic & 2.1982 \\
\hline
\end{tabular}

In the short-run investigation Table 5, The ECT has a sign consistent with econometric theory and it is significant at $1 \%$. The extent of coefficient of ECT makes obvious the speed of variation from shortterm to the long-term path. The above table identified that in the short run DCA and IR are important variables responsible for adjustment in the saving rate in the short run.

\section{Conclusions and Policy Implications}

This article utilizes an ARDL approach to cointegration as proposed by Pesaran and Shin (1999) to examine the long as well as short run associations among dependent and independents variables.

The tentative hypothesis as well as objectives of the study explain in the introduction, are subject to econometric techniques and found the following research findings that there exists a linear relationship between saving rates and its determinants in short run and long run in case of Pakistan.

In order to achieve long run economic growth and development, necessary to overcome the economic problems such as unemployment and poverty, there is a need to increase in the capital formation in the economy. Gross national savings play a critical role in more capital formation which in turn, increases overall productivity. Despite the facts explain in different economic theories and in 
empirical literature regarding the importance of capital formation for growth and development, the condition of gross national saving in Pakistan is not at desirable stage and therefore making capital formation in the economy more difficult which in turn making low per capita real income in Pakistan. In the view of above discussions following recommendations are proposed to promote saving behavior in Pakistan. The government may create more attractive opportunities except to just increase the interest rate in saving accounts. It is also suggested that many financial tools or instruments may have no or little effect on saving behavior, but it may be better complement to other ways of interventions which need to be identified by experts. Similarly, ignorance of information pertain to saving or financial instruments that lead to increase gross national saving and lack of trust in financial institutions may negatively effect on promoting saving behavior that must be overcome by improving efficiency and making people more informative.

\section{References}

Agrawal, P. (2001). The relation between savings and growth: Cointegration and causality evidence from Asia. Applied Economics, 33(4), 499-513.Available at: https://doi.org/10.1080/00036840122210.

Callen, T. (1997). Empirical determinants of household savings. Washington, DC: IMF Working Paper WP/97/181, IMF.

Cardenas, M., \& Escobar, A. (1998). Saving determinants in Colombia: 1925-1994. Journal of Development Economics, Elsevier, $57(1), 5-44$.

Carroll, C. (1991). Consumption growth parallels income growth in, in Bernheim, D. et al, National Savings and Economic Performance.

Cook, C. J. (1995). Savings rates and income distribution: Further evidence from LDCs. Applied Economics, 27(1), 7182.Available at: https://doi.org/10.1080/00036849500000009

Dayal-Ghulati. (1997). Savings in SEA and LA compared: Searching for policy lessons. IMF Working Paper.

Doshi, K. (1994). Factors of the savings rate: An int. Comparison. Contemporary Economics Policy, 12(1), 37-46.

Fry, M. (1995). Money, interest rates and banking in economic development. Baltimore, MD: Johns Hopkins University Press.

Giovannini, A. (1983). The interest elasticity of savings in developing countries: The existing evidence. World Development, 11(7), 601-607.Available at: https://doi.org/10.1016/0305-750x(83)90005-0.

Granger, C. (1969). Investigating causal relations by using econometric and cross-spectral methods. Econometrica, 37, 424438.Available at: https://doi.org/10.2307/1912791.

Granger., C. W. J., \& Paul, N. (1974). Spurious regression in economics. Journal of Econometrics, 4, 111 1-120.

Kelley, A. C. (1988). Population pressures, saving, and investment in the third world: Some puzzles. Economic Development and Cultural Change, 36(3), 449-464.Available at: https://doi.org/10.1086/451669.

Khan, A. H., Hasan, L., \& Malik, A. (1994). Determinants of national saving rate in Pakistan. International Economics, 47(4), 365382.

Leff, N. H. (1969). Dependency rates and savings rates. The American Economic Review, 59(5), 886-896.

MacKinnon, J. G. (1996). Numerical distribution functions for unit root and cointegration tests. Journal of Applied Econometrics, $11,601-618$.

Modigliani, F. (1970). The life-cycle hypothesis and intercountry differences in the saving ratio. In W. A. Eltis, M. FG. Scott, and J. N. Wolfe, Eds., Induction, growth, and trade: essays in honour of Sir Roy Harrod (pp. 197-225). Oxford: Oxford University Press.

Narayan, P. K., \& Saud, A. (2005). An empirical investigation of the determinants of Oman's national savings. Economics Bulletin, 3(51), 1-7.

Nurkse, R. (1953). Problems of capital formation in underdeveloped countries. Oxford: Basil Blackwell.

Pesaran, M. H., \& Shin, Y. (1999). An autoregressive distributed lag modeling approach to cointegration analysis' in $S$ Strom, (ed.), econometrics and economic theory in the 20th century: The ragnar frisch centennial symposium. Cambridge: Cambridge U P.

Sarantis, N., \& Stewart, C. (2001). Saving behaviour in OECD countries: Evidence from panel cointegration tests. The Manchester School, 69, 22-41.Available at: https://doi.org/10.1111/1467-9957.69.s 1.2.

Yule, G. U. (1926). Why do we sometimes get nonsense-correlations between Time-Series?--a study in sampling and the nature of time-series. Journal of the Royal Statistical Society, 89(1), 1-63.Available at: https://doi.org/10.2307/2341482.

Journal of Contemporary Research in Social Sciences
ISSN : 2641-0249
Vol. 2, No. 1, pp. $1-7,2020$
DOI: $10.33094 / 26410249.2020 .21 .1 .7$
C) 2020 by the authors; licensee Learning Gate

